\title{
Calibration and validation of the SWAT model for hydrological simulation in a basin in Western Bahia
}

Hydrological modeling presents itself as a fundamental tool for the management and management of water resources, since it helps in understanding the streamflow, sediments and contaminants in a hydrographic basin. The Correntina River basin, located in the western region of Bahia, has been undergoing an intense process of alteration in its landscape motivated by the expansion of agricultural areas in the region, requiring the adoption of instruments for studies that assess the environmental impacts mainly on surface water resources. In view of this, the present study aimed to evaluate the effectiveness of the SWAT model for representing the hydrological behavior in the basin of the Correntina River, using the SWAT-CUP for automatic calibration and validation. Statistical performance coefficients attested the model's capacity for hydrological simulations in this basin on a monthly time scale, with KGE, Pbias, NSE and $R^{2}$ showing values of 0.69 , $0.57,0.5 \%$ and 0.74 in the calibration stage, and $0.73,-3.95 \%, 0.64$ and 0.76 in the validation step, respectively. In addition, the SWAT was also shown to be suitable for simulating the flow duration curves, characterizing the model as a good tool to aid the management of water resources in the basin under study. Subsequent studies will make it possible to analyze the impacts of land use and climate change on the hydrological behavior of the Correntina river basin.

\section{Calibração e validação do modelo SWAT para simulação hidrológica em uma bacia do Oeste da Bahia}

\begin{abstract}
A modelagem hidrológica se apresenta como uma ferramenta fundamental para gestão e gerenciamento dos recursos hídricos, visto que ela auxilia na compreensão do fluxo da água, sedimentos e contaminantes em uma bacia hidrográfica. A bacia do rio Correntina, localizada na região oeste da Bahia, vem sofrendo um intenso processo de alteração em sua paisagem motivado pela expansão das áreas agrícolas na região, sendo necessária a adoção de instrumentos para estudos que avaliem os impactos ambientais principalmente nos recursos hídricos superficiais. Visto isso, o presente trabalho teve como objetivo avaliar a eficácia do modelo SWAT para representação do comportamento hidrológico na bacia hidrográfica do rio Correntina, utilizando o SWAT-CUP para calibração e validação automáticas. Os coeficientes estatísticos de desempenho atestaram a capacidade do modelo para as simulações hidrológicas nessa bacia em escala temporal mensal, com KGE, Pbias, NSE e $R^{2}$ apresentando valores de $0.69,0.57,0.5 \%$ e 0.74 na etapa de calibração, e $0.73,-3.95 \%, 0.64$ e 0.76 na etapa de validação, respectivamente. Além disso, o SWAT também se mostrou adequado para simulação das curvas de permanência, caracterizando o modelo como uma boa ferramenta de auxílio a gestão dos recursos hídricos na bacia em estudo. Estudos posteriores permitirão analisar os impactos do uso do solo e mudanças climáticas no comportamento hidrológico da bacia do rio Correntina.
\end{abstract}

Palavras-chave: Modelagem hidrológica; Rio Correntina; Vazão.

Topic: Engenharia de Recursos Hídricos

Reviewed anonymously in the process of blind peer
Received: 02/01/2021

Approved: 27/01/2021
Lorena Lima Ferraz (iD

Universidade Estadual de Santa Cruz, Brasil http://lattes.cnpq.br/2679970266851969 http://orcid.org/0000-0003-3997-1069 lorenalferraz@gmail.com

Lucas Farias de Sousa (iD)

Universidade Estadual de Santa Cruz, Brasil

http://lattes.cnpq.br/6855382097221938

http://orcid.org/0000-0003-3152-2330

eng.sousalucas@gmail.com

Lorena Souza da Silva (iD)

Universidade Estadual do Sudoeste da Bahia, Brasil

http://lattes.cnpq.br/4600993467226194

http://orcid.org/0000-0002-2699-7406

loriesouza@hotmail.com

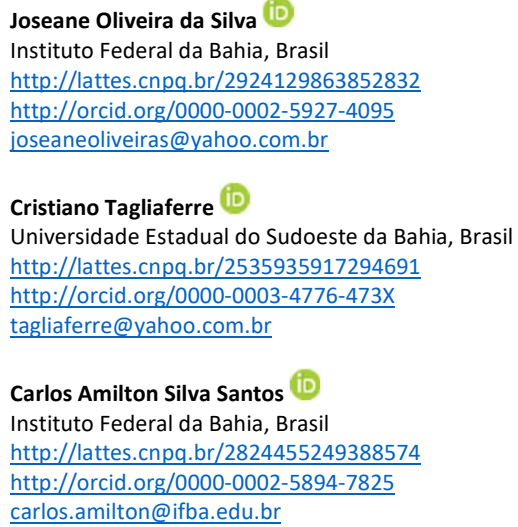

Felizardo Adenilson Rocha (iD Instituto Federal da Bahia, Brasil http://lattes.cnpq.br/1581393124834413 http://orcid.org/0000-0001-6410-5176 felizardoar@hotmail.com
Referencing this:

FERRAZ, L. L.; SOUSA, L. F.; SILVA, L. S.; SILVA, J. O.; TAGLIAFERRE, C.; SANTOS, C. A. S.; ROCHA, F. A.. Calibration and validation of the SWAT model for hydrological simulation in a basin in Western Bahia. Revista Ibero Americana de Ciências Ambientais, v.12, n.1, p.276-285, 2021. DOI: http://doi.org/10.6008/CBPC2179-6858.2021.001.0023 


\section{INTRODUCTION}

The western region of Bahia, in which the hydrographic basin of the Correntina river is inserted, underwent an intense process of economic transformation from the first half of the 1980s, due to the introduction of a modern and sophisticated agricultural system (SANTOS et al., 2018). Thus, the occupation of the rural area and the exploitation of natural resources, especially water resources, occurred (and still occur) in a disorderly and predatory manner, requiring that the government adopt measures to minimize environmental impacts through the efficient management of these resources (BAHIA, 1995).

To assist the management and preservation of water resources, understanding the hydrological behavior and analyzing the physical characteristics of a watershed is essential (BALBINOT et al., 2008). One of the scientific means for these studies and obtaining answers to the real effects of changes in the basin is through the modeling of environmental systems, which have aroused interest in the scientific community in general. This tool allows the representation of climatic, hydrological, hydraulic processes, water quality, environmental conditions, operational and economic aspects.

According to Ribeiro et al. (2017), modeling and geoprocessing are shown as a set of technologies of paramount importance for the study of river basins and sub-basins, and in this way, the government administration can find in this tool an important ally for the management of the water resources.

In the modeling of environmental systems, the use of hydrological models stands out, which allows the study and assessment of water balance on a spatial and temporal scale (TUCCI, 2005). These models have been gaining space by presenting themselves as an efficient instrument for assessing the hydrological behavior of watersheds, with Soil Water Assessment Tools (SWAT) being one of the most used and internationally known for showing itself as a robust interdisciplinary tool with regard to the modeling of hydrological processes (GASSMAN et al., 2007).

SWAT is a mathematical model in the public domain, with a semi-distributed and continuous parameter, which allows different physical processes to be simulated in the watershed (ARNOLD et al., 2012). According to Aragão et al. (2013), for predicting the impacts of human actions or climate change on hydrological processes, models with these characteristics have been quite effective.

Several studies used the SWAT in order to analyze the impacts of changes in land use and climate changes on the surface and underground runoff, sediment production, water quality, as well as pesticide transport. Santos et al. (2019), studying the effects of climate change in the Paraguaçu River basin using the SWAT model, demonstrated the reduction of surface flow in all climate change scenarios, relevant information to guide the future management of water resources in the region. Marmontel et al. (2019), evaluating the applicability of the SWAT model in the Paraibuna River basin, concluded that the model can serve as a tool for planning and managing public policies for water resources in river basins in the Atlantic Forest region. Dash et al. (2020) identified vulnerable areas under climate change scenarios in India with the SWAT model.

Given the above, taking into account the wide range of application of the SWAT model and its 
potential as a tool to aid the management of water resources, in addition to the absence of such studies in the western region of Bahia, the present study aimed to evaluate the effectiveness of the SWAT model to represent the hydrological behavior in the Correntina River basin, whose area currently occupied by agriculture is $35 \%$, and the region is facing, at the same time, an intense water crisis due to the reduction in the availability of surface water.

\section{MATERIALS AND METHODS}

\section{Location and characterization of the study area}

The Correntina River basin is located in the western region of the state of Bahia (Figure 1), occupying an area of $3852 \mathrm{~km}^{2}$. It is one of the main tributaries of the São Francisco River. According to the Köppen (1931) classification, the climate in the region is classified as a Tropical sub-humid with summer rains (Aw), with a well-defined dry period in winter.

The course of the Correntina River is $220 \mathrm{~km}$ long, with its entire area inserted in the territory of the Correntina city. The region has typical Cerrado vegetation, with an area of natural vegetation divided between areas of savanna and rural formations, where the latter has extensive areas of dirty fields.

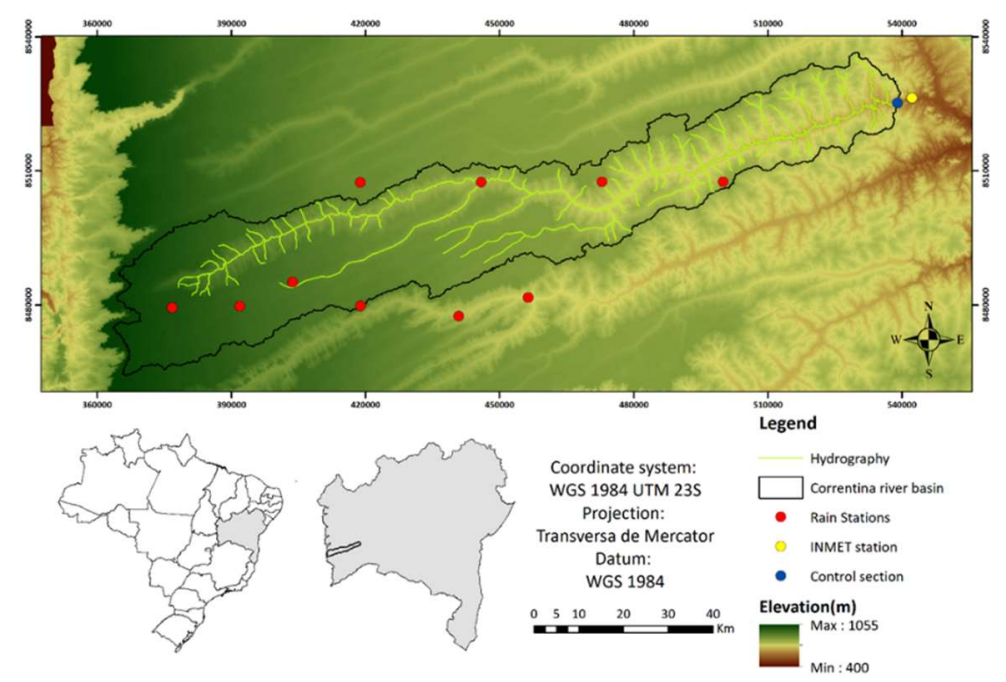

Figure 1: Location of the study area and climatic stations used.

\section{Input database}

For the use of the model, the following input data were needed: map of land use and occupation, type of soil, meteorological and rainfall conditions (precipitation, relative humidity, temperature, solar radiation and wind speed) and digital elevation model. According to Tucci (2005), the quantity and quality of data for calibration and validation of hydrological models are essential to allow satisfactory results.

The land use and occupation maps were obtained through the MapBiomas Project - Collection 4.1 of the 'Annual series of land use and coverage maps of Brazil'. The Project is a multi-institutional initiative that aims to generate annual maps of land cover and use from automatic classification processes applied to satellite images. Among the classes of land use and occupation in the Correntina River basin, agricultural 
areas (AGRR) occupy $35 \%$ of the total area of the basin, followed by areas with savanna formation (RNGB), rural formation (RNGE), pasture (PAST), and forests (FRSD), with $31 \%, 26 \%, 4 \%$ and $4 \%$ of the study area, respectively.

The soil type maps were obtained from the open database of the Brazilian Agricultural Research Corporation (Embrapa). The predominant soils of the basin were the red-yellow Latosol, Neossolo Quartzarênico and Cambisolo Háplico, occupying, respectively, $47.9 \% ; 51.43 \%$ and $0.67 \%$ of the total area of the basin (Figure 2).

Precipitation data were acquired from the Hidroweb platforms of the National Water Agency (ANA) and Agritempo, while the other meteorological variables were acquired from the National Meteorological Institute (INMET). The solar radiation data were obtained through the grid of meteorological variables elaborated by Xavier et al. (2015). The monitoring of the basin under study is carried out by an ANA station (code 45590000), in the basin control section, located in the city of Correntina (Figure 1). To fill in the gaps present in the historical series of meteorological data, WXGEN was used, a model that generates the atmospheric state of the climate in the SWAT model, which simulates the series of climatic data or fills in gaps based on recorded data.

For this, some statistics from the historical series of observed data were calculated to feed the tool, such as TMPMX: Maximum temperature $\left({ }^{\circ} \mathrm{C}\right)$; TMPMN: Minimum temperature $\left({ }^{\circ} \mathrm{C}\right)$; TMPSTDMX: Standard deviation from the maximum temperature $\left({ }^{\circ} \mathrm{C}\right)$; TMPSTDMN: Standard deviation of the minimum temperature $\left({ }^{\circ} \mathrm{C}\right)$; PCPMM: Average precipitation (mm/day); PCPSTD: Standard deviation of daily precipitation (mm/day); PCPSKW: Slope coefficient for daily precipitation; PR_W1_: Probability of rainy day after dry day; PR_W2_: Probability of rainy day after rainy day; PCPD: Average number of rainy days (day); RAINHHMX: Maximum precipitation of $0.5 \mathrm{~h}(\mathrm{~mm})$; SOLARAV: Average solar radiation $\left(\mathrm{MJ} / \mathrm{m}^{2} / \mathrm{d}\right)$; DEWPT: Average dew point temperature $\left({ }^{\circ} \mathrm{C}\right)$; WNDAV: Average wind speed $(\mathrm{m} / \mathrm{s})$; and RAIN_YRS: Number of years of data used to determine values for RAIN_HHMX (year). To obtain these statistics, the SWAT Weather Database was used, a tool developed by Essenfelder (2016) that calculates these parameters based on the inserted historical data series.

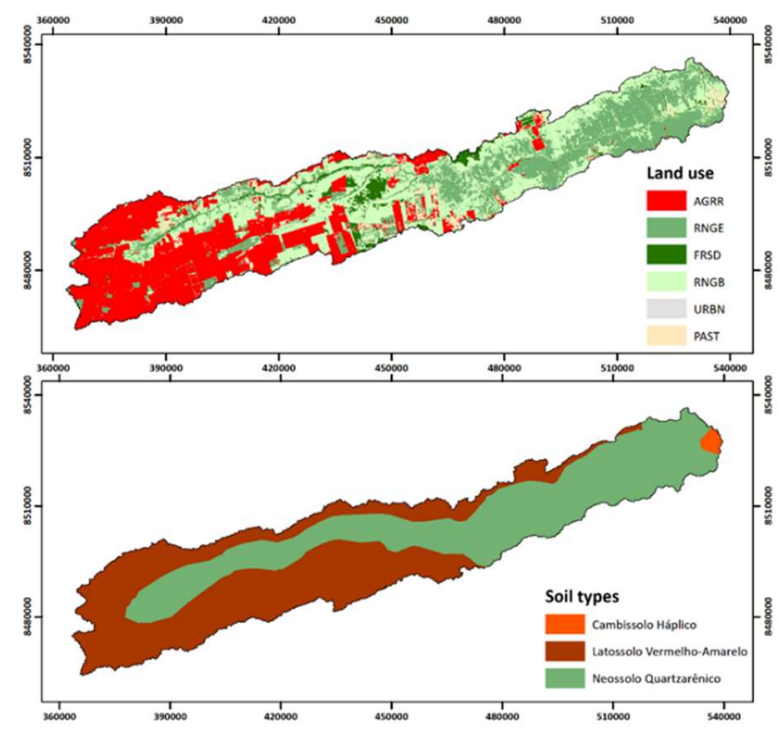

Figure 2: Maps of land use and soil types. 
The Digital Elevation Model (DEM), with a spatial resolution of $30 \mathrm{~m}$ was acquired through the TOPODATA project, from the Shuttle Radar Topographic Mission (SRTM), whose data are made available by the United States Geological Survey (USGS).

\section{Soil and Water Assessment Tools (SWAT)}

Hydrological models seek a way to describe the behavior of a hydrographic basin, in addition to representing the portion of the hydrological cycle that transforms precipitation into the flow (TUCCI, 2005). For these analyzes it is necessary to use hydrological models with a physical and/or empirical basis, being SWAT (Soil and Water Assessment Tool) currently a prominent model worldwide.

SWAT was developed to analyze the hydrological dynamics, sediment and pesticide transport in watercourses. In addition, it also allows simulations to be carried out to assess the impacts of changes in land use and climate change in river basins (ARNOLD et al., 2012). In the SWAT model, the equation of the water balance continuity is used, integrating all models that estimate each component of the hydrological cycle, as described in Equation 1.

$$
S W_{t}=S W_{0}+\sum_{i=1}^{t}\left(R_{\text {day }}-Q_{\text {surf }}-E_{a}-W_{\text {seep }}-Q_{g w}\right)
$$

Where $S W_{t}$ is the final amount of water in the soil $(\mathrm{mm}), S W_{0}$ is the initial soil moisture on the day $i$ $(\mathrm{mm}), t$ is the time (days), $R_{\text {day }}$ is the amount of precipitation on the day $i(\mathrm{~mm}), Q_{\text {surf }}$ is the amount of runoff in the day $i(\mathrm{~mm}), E_{a}$ is evapotranspiration on the day $i(\mathrm{~mm}), W_{\text {seep }}$ is the amount of water that leaves the aeration zone of the soil profile on the day $i(\mathrm{~mm}), Q_{g w}$ is the amount of flow return in the day $i(\mathrm{~mm})$.

SWAT has three models associated with the calculation of evapotranspiration for the simulation, namely Penman-Monteith, Hargreaves-Samani, and Priestley-Taylor, where the choice of the method to be used is associated with the climatic characteristics of the basin as well as the availability of data. In the present study, evapotranspiration was calculated using the Penman-Monteith method. The runoff was estimated using the SCS (Soil Conservation Service) curve number method, and the propagation in the channel was simulated by the variable storage method.

\section{Calibration and Validation}

The calibration of the SWAT model for the hydrographic basin of the Correntina river was performed automatically by the SWAT-CUP software, using the SUFI2 algorithm (Sequential Uncertainty Fitting). The simulation was performed on the monthly time scale, with a calibration period between January 1st of 2006 and December 31th of 2010, and validation between January 1st of 2011 and December 31th of 2015.

The basin under study was discretized into 21 sub-basins, later subdivided into 215 Hydrological Response Units (HRU), which allow the model to reflect the hydrological conditions for different slopes, cover and soil types on a small scale.

Ten parameters were used to be calibrated for the flow simulation, defined after conducting the sensitivity analysis. In the calibration process, the relative and replace methods were used. In SWAT there 
are three methodologies to define the alteration of the parameters within the established limits, and through successive interactions, it is possible to know which parameters of the model are the most sensitive, being the replacement, absolute and relative methods. The replacement method changes the value directly, in absolute, a constant value is added to the initial value of the parameter and in the relative method, the change of values is established by varying the initial value by percentage.

Subsequently, the hydrographs were analyzed at each iteration and the parameters that affected peak flows had their intervals modified until the minimization of errors between the model outputs and the measured data. Finally, the validation step was performed with the parameters already adjusted after the calibration step. According to Medeiros et al. (2018), the validation aims to verify whether the model is capable of simulating data from other periods or conditions other than which it was calibrated.

\section{Criteria for evaluating the model}

To evaluate the performance of the model, four statistics were used: the Nash-Sutcliffe coefficient (NSE), the percentage of bias (Pbias), coefficient of determination $\left(R^{2}\right)$ and the Kling-Gupta Efficiency (KGE). The NSE, whose calculation is based on Equation 2, indicates how much the graph of observed versus simulated data fits and varies from less infinite to 1 , where 1 represents the perfect fit. This coefficient is indicated for long-term continuous simulations and can be used to determine how well the model simulates trends for the output response of interest (MORIASI et al., 2015).

$$
N S E=\left[1-\frac{\sum_{i=1}^{n}\left(Q_{o, i}-Q_{s, i}\right)^{2}}{\sum_{i=1}^{n}\left(Q_{o, i}-Q_{o, m}\right)^{2}}\right]
$$

The percentage of bias is calculated according to Equation 3 and represents the deviation between observed and simulated data, expressed as a percentage. The Pbias value varies between less and more infinite, with zero as the optimal value, that is, the closer to 0 , the better the model's performance. Negative and positive values indicate the overestimation or underestimation of the modeling, respectively.

$$
\text { Pbias }=\left[\frac{\sum_{i=1}^{n}\left(Q_{o, i}-Q_{s, i}\right)}{\sum_{i=1}^{n} Q_{o, i}}\right] \cdot 100
$$

The coefficient of determination $\left(R^{2}\right)$ is widely used in hydrological modeling studies, and describes the degree of collinearity between simulated and observed data, and, according to Equation 4, varies between 0 and 1 , with 1 being the optimal value.

$$
R^{2}=\left[\frac{\sum_{i=1}^{n}\left(Q_{o, i}-Q_{o, m}\right)\left(Q_{s, i}-Q_{s, m}\right)}{\sqrt{\sum_{i=1}^{n}\left(Q_{o, i}-Q_{o, m}\right)^{2}} \sqrt{\sum_{i=1}^{n}\left(Q_{s, i}-Q_{s, m}\right)^{2}}}\right]^{2}
$$

Gupta et al. (2009) developed an objective function called KGE (Kling-Gupta Efficiency) based on the decomposition of the Nash-Sutcliffe coefficient and the Mean Square Error (FRANCO et al., 2017). Like the Nash-Sutclif coefficient, KGE values range from - $\infty$ to 1 , with 1 being the best fit.

$$
K G E=1-\sqrt{(r-1)^{2}+(\beta-1)^{2}+(\alpha-1)^{2}}, \alpha=\frac{\mu_{s}}{\mu_{o}} ; \beta=\frac{\sigma_{s}}{\sigma_{o}}
$$

In Equations 2, 3, 4 and 5, $\mathrm{n}$ is the number of observed and simulated pairs; $Q_{o}$ is the observed flow, 
$Q_{S}$ is the simulated flow, $Q_{o, m}$ is the average observed flow and $Q_{s, m}$ is the simulated average flow. In Equation $5, r$ is the linear correlation coefficient; $\mu_{o}$ and $\mu_{s}$ are the arithmetic means of the observed and simulated values; $\sigma_{o}$ and $\sigma_{s}$ represent the standard deviation of observed and simulated values.

Table 1: Criteria for assessing the performance of the hydrological model and range of variation values.

\begin{tabular}{|c|c|c|c|c|c|}
\hline \multirow{2}{*}{ Coefficient } & \multicolumn{5}{|c|}{ Performance evaluation criteria } \\
\hline & Very Good & Good & Satisfactory & Unsatisfactory & Range \\
\hline $\mathrm{R}^{2}$ & $R^{2}>0.85$ & $0.75<R^{2} \leq 0.85$ & $0.60<R^{2} \leq 0.75$ & $R^{2} \leq 0.60$ & -1 a 1 \\
\hline NSE & NSE $>0.80$ & $0.70<\mathrm{NSE} \leq 0.80$ & $0.50<\mathrm{NSE} \leq 0.70$ & $\mathrm{NSE} \leq 0.50$ & $-\infty$ a 1.0 \\
\hline PBIAS (\%) & PBIAS $< \pm 5$ & $\pm 5 \leq$ PBIAS $< \pm 10$ & $\pm 10 \leq$ PBIAS $< \pm 15$ & PBIAS $\geq \pm 15$ & $-\infty$ a $\infty$ \\
\hline KGE & KGE $>0.75$ & $0.75<\mathrm{KGE} \leq 0.50$ & $0.50<\mathrm{KGE} \leq 0.0$ & KGE $\leq 0.0$ & $-\infty$ a 1.0 \\
\hline
\end{tabular}

Source: Moriasi et al. (2015) and Thiemig et al. (2013).

\section{RESULTS AND DISCUSSION}

Table 2, shown below, lists the parameters indicated by the sensitivity analysis as those that most affect the model's output for the area under study. Because most parameters are difficult to estimate and measure in the field, their initial range of variation was adopted based on the values described in the analyzed literature, as suggested by Blainski et al. (2017).

Tabela 2: Parâmetros calibrados pelo modelo SWAT na simulação da vazão.

\begin{tabular}{lllll}
\hline Ranking & Parameter & Description & Default & $\begin{array}{l}\text { Calibrated } \\
\text { values }\end{array}$ \\
\hline 1 & r_CN2.mgt & SCS runoff curve number for moisture condition II & $39-79$ & -0.71 \\
\hline 2 & v_RCHRG_DP.gw & Deep aquifer recharge $(\mathrm{mm})$ & 0.05 & 0.75 \\
\hline 3 & v_ESCO.hru & Soil evaporation compensation factor & 0.95 & 0.98 \\
\hline 4 & v_GWQMN.gw & $\begin{array}{l}\text { Threshold depth of water in the shallow aquifer for return flow to } \\
\text { occur (mm) }\end{array}$ & 1000 & 1951.5 \\
\hline 5 & v_REVAPMN.gw & Revaporation coefficient & 750 & 13.0 \\
\hline 6 & r_SOL_AWC.sol & Available water capacity of the first soil layer (mm.mm-1) & $0.05-$ & 0.09 \\
\hline 7 & v_GW_REVAP.gw & Coef. de ascenção da água à zona saturada & 0.3 & 0.02 \\
\hline 8 & v_GW_DELAY.gw & Groundwater Delay (days) & 0.13 \\
\hline 9 & r_SOL_K.sol & Saturated hydraulic conductivity of first soil layer (mm.h-1) & 31 & 497 \\
\hline 10 & v_ALPHA_BF.gw & Base runoff recession coefficient (days) & 100 & -0.1 \\
\hline
\end{tabular}

$r_{-}$: relative method; $v_{-}$: replacement method;

After conducting the sensitivity analysis, calibration and validation of the parameters, the SWAT model was considered able to simulate monthly flows in the Correntina River basin, since the statistical coefficients (Table 3 ) obtained on the monthly time scale attest to a good performance.

Table 3: Performance statistics of the SWAT model for calibration and validation on the monthly time scale.

\begin{tabular}{|c|c|c|c|c|c|c|c|}
\hline \multirow[b]{2}{*}{ Process } & \multirow{2}{*}{ Period } & \multicolumn{2}{|c|}{ Average streamflow $\left(\mathrm{m}^{3} / \mathrm{s}\right)$} & \multicolumn{4}{|c|}{ Estatistics } \\
\hline & & Observed & Simulated & NSE & PBIAS & $\mathbf{R}^{2}$ & KGE \\
\hline Calibration & $2006-2010$ & 27.88 & 28.01 & 0.57 & 0.5 & 0.74 & 0.69 \\
\hline Validation & 2011-2015 & 27.61 & 26.52 & 0.64 & -3.95 & 0.76 & 0.73 \\
\hline
\end{tabular}

In the calibration step, the NSE was 0.57. According to the evaluation criteria developed by Moriasi et al. (2015) and described in Table 1, the model presented a performance considered "satisfactory" in the calibration stage. In the validation stage, the value of the Nash-Sutcliffe coefficient improved, with its value jumping to 0.64 , and just as in the calibration stage, the model was considered "satisfactory". Several authors used the SWAT model to simulate monthly flows, obtaining good values for statistical coefficients. Andrade 
et al. (2013), performing the hydrological simulation in a watershed in the Alto Rio Grande-MG region, found values of the Nash-Sutcliffe coefficient of 0.66 . Santos et al. (2018), calibrating the SWAT model in three subbasins in the semi-arid region of Northeast Brazil, obtained the NSE coefficient for calibration and validation of 0.86 and 0.76 , respectively, for monthly flows in the river sub-basin. Andaraí.

In the calibration and validation stage, the Pbias value was 0.5 and -3.95 , respectively, a performance considered "very good". Brighenti et al. (2016), using the SWAT model in a Santa Catarina watershed, found Pbias values of $0.1 \%$ and $2.6 \%$ during the calibration and validation stages, respectively, indicating slight underestimations of the model. Pereira et al. (2014), after carrying out the hydrological simulation using the SWAT in a watershed at the head of the coastal region of Brazil, obtained Pbias values of 0.70 and $-4.8 \%$, in the calibration and validation, in that order.

The values obtained from the $\mathrm{R}^{2}$ statistic during the calibration and model validation stage were 0.74 and 0.76 , respectively. Therefore, the model can be classified as "satisfactory" and "good", in that order, according to Moriasi et al. (2015). Almeida et al. (2018), performing the SWAT calibration and validation for the Mucuri River watershed found the correlation coefficient for calibration with the value of 0.65 and 0.62 for validation. Silva et al. (2017) using the SWAT to estimate the flow in a hydrographic sub-basin of the Jequitinhonha River, obtained values of 0.62 and 0.75 for calibration and validation, respectively.

In the calibration step, the KGE was 0.69. According to the evaluation criteria described by Thiemig et al. (2013), the model performed as "good" in the calibration stage. In the validation stage, the value of the Kling-Gupta efficiency coefficient improved, with its value jumping to 0.73 , and as in the calibration stage, the model was considered "good". Several authors have used this statistic to evaluate the efficiency of modeling jointly with PBIAS, NSE and $\mathrm{R}^{2}$. Franco et al. (2017), calibrating and validating the SWAT model for the Negro River basin, reached values of 0.67 for KGE in the calibration stage and 0.77 in the validation. Bisselink et al. (2016) obtained performance classified as intermediate of the calibrated model in a basin in Southwest Africa.

Through the evaluation and review criteria of available works, the results obtained in the calibration of the SWAT for the Correntina River basin are within the acceptable range for the model to be used in the hydrological simulation of the basin under study, according to the NSE statistical coefficients, Pbias, $\mathrm{R}^{2}$ and KGE.

An important analysis of the performance of a hydrological model is realized by assessing the fit of the simulated and observed results using the hydrograph (Figure 2), making it possible to notice that in some periods of low flow the model underestimates the observed data. According to Aragão et al. (2013), this behavior is associated with the fact that the model is unable to reproduce the groundwater process well in this period because it is a significant component in the dry season, since in basins under aquifers, the surface flow is maintained by the underground reserves.

According to Blainski et al. (2017), a useful analysis to be performed after the calibration and validation stage is the ability of hydrological models to generate reliable data for the construction of the flow duration curve (Figure 3), which are essential tools in the preparation of river basin plans. 
Regarding the maximum flow values, the model overestimated its values by $10 \%$; however, the percentage of overestimation was within acceptable limits, as well as the underestimation of the minimum flow rates, which was $11 \%$. There was an excellent adjustment of the average flow rates between 20 to $70 \%$ of permanence. Pereira et al. (2014) stated that errors of up to $30 \%$ in simulated flows are considered satisfactory for granting water grants in irrigated areas of Brazil. Thus, the SWAT model proved to be suitable for simulating flows on a monthly time scale in the Correntina River basin, making it possible to carry out studies on flood forecasting, analysis of changes in land use in the flow regime, water balance, and impacts of climate change on the hydrological behavior of the region.

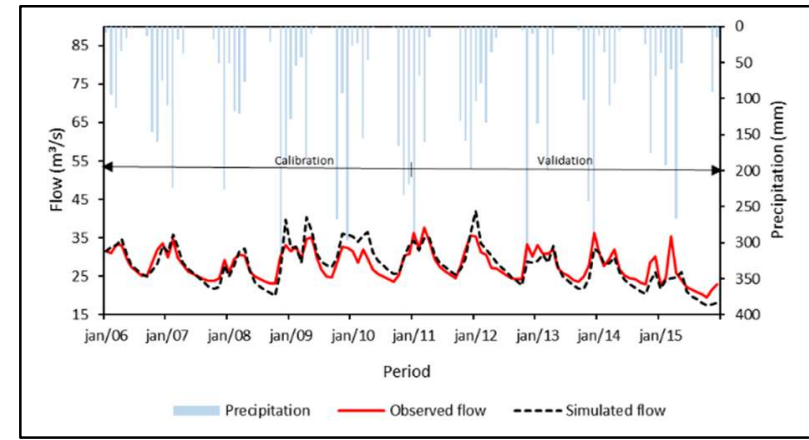

Figure 2: Hydrograph of the simulated and observed flows and hietogram for the calibration (2006-2010) and validation (2011-2015) periods.

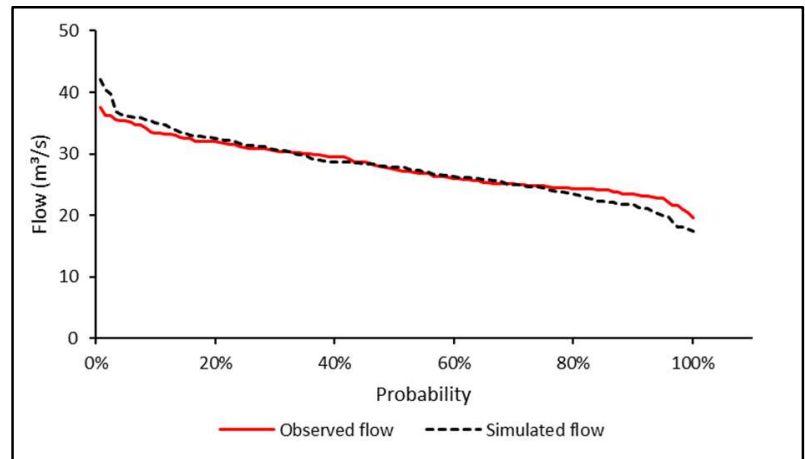

Figure 3: Observed and simulated flow duration curve.

\section{CONCLUSIONS}

The Correntina River basin proved to be suitable for the execution of the methods described in this study. According to the values obtained for the performance coefficients, the SWAT model is capable of satisfactorily simulating the monthly streamflow rates after the automatic calibration and validation steps. Subsequent studies will make it possible to analyze the impacts of land use and climate change on the hydrological behavior of the basin under study.

The analysis of the flow duration curve showed that the model can be used to assist in water management, presenting an overestimation of the highest flows resulting from extreme events, and underestimating the flows with minimal probabilities of exceedance, but within an acceptable range of error. Therefore, the present study attested to the applicability of the model as a management and planning tool for water resources in the Correntina River basin.

\section{REFERENCES}

ALMEIDA, R. A.; PEREIRA, S. B.; PINTO, D. B. F.. Calibração e Validação do Modelo Hidrológico SWAT para a bacia hidrográfica do rio Mucuri. Engenharia Agrícola, v.38, n.1, 2018.

ANDRADE, M. A.; MELLO, C. R.; BESKOW, S.. Simulação hidrológica em uma bacia hidrográfica representativa dos Latossolos na região Alto Rio Grande, MG. Revista Brasileira de Engenharia Agrícola e Ambiental, v.17, n.1, p.69-76, 2013. DOI: $h$ ttp://dx.doi.org/10.1590/S1415$\underline{43662013000100010}$
ARAGÃO, R.; CRUZ, M. A. S.; AMORIM, J. R. A.; MENDONÇA, L. C.; FIGUEIREDO, E. E.; SRINIVASAN, V. S.. Análise de sensibilidade dos parâmetros do modelo SWAT e simulação dos processos hidrossedimentológicos em uma bacia no agreste nordestino. Revista Brasileira Ciência do Solo, v.37, n.4, p.1091-1102, 2013. DOI: http://dx.doi.org/10.1590/S0100-06832013000400026

ARNOLD, J.G.; MORIASI, D. N.; GASSMAN, P. W.; ABBASPOUR, K. C.; WHITE, M. J.. SWAT: Model use, 
calibration, and validation. Transactions of the ASABE, v.55, n.4, p.1491-1508, 2012. DOI:

http://dx.doi.org/10.13031/2013.42256

BAHIA. Governo do Estado. Plano diretor de recursos hídricos: bacia do rio Corrente. Salvador: HIGESA, 1995.

BALBINOT, R.; OLIVEIRA, N. K.; VANZETTO, S. C.; PEDROSO, K.; VALÉRIO, A. F.. O papel da floresta no ciclo hidrológico em bacias hidrográficas. Ambiência, v.4, n.1, 2008.

BISSELINK, B.; ZAMBRANO-BIGIARINI, M.; BUREK, P.; ROO, A.. Assessing the role of uncertain precipitation estimates on the robustness of hydrological model parameters under highly variable climate conditions. Journal of Hydrology: Regional Studies, v.8, p.112-129, 2016. DOI: https://doi.org/10.1016/j.ejrh.2016.09.003

BLAINSKI, E.; ACOSTA, E.; NOGUEIRA, P. C. P.. Calibração e validação do modelo SWAT para simulação hidrológica em uma bacia hidrográfica do litoral norte catarinense. Ambiente \& Água, v.12, n.2, p.226-237, 2017. DOI: https://doi.org/10.4136/ambi-agua.1951

BRIGHENTI, T. M.; BONUMÁ, N. B.; CHAFFE, P. L. B. Calibração hierárquica do modelo SWAT em uma bacia hidrográfica Catarinense. Revista Brasileira de Recursos Hídricos, v.21, n.1 p.53-64, 2016. DOI: http://dx.doi.org/10.21168/rbrh.v21n1.p53-64

DASH, S. S.; SENA, D. R.; MANDAL, U.; KUMAR, A.; KUMAR, G.; MISHRA, P. K.; RAWAT, M.. A hydrological modellingbased approach for vulnerable area identification under changing climate scenarios. Journal of Water and Climate Change, p.1-20, 2020. DOI:

https://doi.org/10.2166/wcc.2020.202

ESSENFELDER, A. H.. SWAT weather database: a quick guide. SWAT, 2018.

FRANCO, A. C. L.; BONUMÁ, N. B.. Multi-variable SWAT model calibration with remotely sensed evapotranspiration and observed flow. Revista Brasileira de Recursos Hídricos, v.22, n.35, 2017. DOI: https://doi.org/10.1590/2318$\underline{0331.011716090}$

GASSMAN, P. W.; REYES, M. R.; GREEN, C. H.; ARNOLD, J. G.. The soil and water assessment tool: historical development, applications, and future research directions. Transaction of the ASABE, v.50, p.1211-1250, 2007. DOI: http://dx.doi.org/10.13031/2013.23637

GUPTA, H. V.; KLING, H.; YILMAZ, K. K.; MARTINEZ, G. F.. Decomposition of the mean squared error and NSE performance criteria: implications for improving hydrological modelling. Journal of Hydrology, v.377, n.1-2, p. 80-91, 2009. DOI: https://doi.org/10.1016/i.jhydrol.2009.08.003

KÖPPEN, W.. Grundriss der klimakunde: outline of climate science. Berlin: Walter de Gruyter, 1931.
MARMONTEL, C. V. F.; PISSARRA, T. C. T.; RANZINI, M. E.; RODRIGUES, V. A.. Aplicabilidade do modelo hidrológico SWAT na bacia hidrográfica do rio Paraibuna, SP, Brasil. Irriga, v.24, n.3, p.594-609, 2019. DOI:

http://dx.doi.org/10.15809/irriga.2019v24n3p594-609

MEDEIROS, I. C.; SILVA, J. F. C. B. C.; SILVA, R. M.; SANTOS, C. A. G.. Run-offerosion modelling and water balance in the Epitácio Pessoa Dam river basin, Paraíba State in Brazil. International Journal of Environmental Science and Technology, v.16, p.3035-3048, 2018. DOI: https://doi.org/10.1007/s13762-018-1940-3

MORIASI, D. N.; GITAU, M. W.; PAI, N.; DAGGUPATI, P.. Hydrologic and water quality models: Performance measures and evaluation criteria. Trans. ASABE, v.58, n.6, p.1763-1785, 2015. DOI: https://doi.org/10.13031/trans.58.10715

PEREIRA, D. D. R.; MARTINEZ, M. A.; ALMEIDA, A. Q.; PRUSKI, F. F.; SILVA, D. D.; ZONTA, J. H.. Hydrological simulation using SWAT model in headwater basin in Southeast Brazil. Eng. Agríc., v.34, n.4, p.789-799, 2014. DOI: http://dx.doi.org/10.1590/S0100-69162014000400018

RIBEIRO, J.; SCHIEBELBEIN, L. M.. O Geoprocessamento como ferramenta de gestão urbana. Revista TechoEng, v.1, n.14, p.13-22, 2017.

SANTOS, C. A. S.; ALMEIDA, C.; RAMOS, T. B.; ROCHA, F. A.; OLIVEIRA, R.; NEVES, R.. Using a Hierarchical Approach to Calibrate SWAT and Predict the Semi-Arid Hydrologic Regime of Northeastern Brazil. Water, v.10, n.9, p.1137, 2018. DOI: https://doi.org/10.3390/w10091137

SANTOS, C. A. S.; ROCHA, F. A.; RAMOS, T. B.; ALVES, L. M.; MATEUS, M.; OLIVEIRA, R. P.; NEVES, R.. Using a Hydrologic Model to Assess the Performance of Regional Climate Models in a Semi-Arid Watershed in Brazil. Water, v.11, n.170, p.1-17, 2019. DOI:

https://doi.org/10.3390/w11010170

SILVA, N. D. M.; CHRISTOFARO, C.. Calibração do modelo hidrológico SWAT para estimativa da vazão em sub-bacia hidrográfica do Rio Jequitinhonha. Revista Geografias, p.3139, 2017.

THIEMIG, V.; ROJAS, R.; ZAMBRANO-BIGIARINI, M.; ROO, A. Hydrological evaluation of satellite-based rainfall estimates over the Volta and Baro-Akobo Basin. Journal of Hydrology, v.499, p.324-338, 2013. DOI:

https://doi.org/10.1016/i.jhydrol.2013.07.012

TUCCI, C. E. M.. Modelos hidrológicos. 2 ed. Porto Alegre: ABRH, 2005.

XAVIER, A. C.; KING, C. W.; SCANLON, B. R.. Daily gridded meteorological variables in Brazil (1980-2013). International Journal of Climatology, v.36, n.6, p.2644-2659, 2015. DOI: https://doi.org/10.1002/joc.4518

A CBPC - Companhia Brasileira de Produção Científica (CNPJ: 11.221.422/0001-03) detém os direitos materiais desta publicação. Os direitos referem-se à publicação do trabalho em qualquer parte do mundo, incluindo os direitos às renovač̃os, expansões e disseminações da contribuiç̃o, bem como outros direitos subsidiários. Todos os trabalhos publicados eletronicamente poderão preservam os direitos autorais, mas não têm permissão para a publicação da contribuição em outro meio, impresso ou digital, em português ou em tradução. 